\title{
A problematic animal fossil from the early Cambrian Hetang Formation, South China
}

\author{
Qing Tang, ${ }^{1}$ Jie Hu,${ }^{2}$ Guwei Xie, $, 34,5$ Xunlai Yuan, ${ }^{6,7}$ Bin Wan, ${ }^{6}$ Chuanming Zhou, ${ }^{8}$ Xu Dong, ${ }^{9}$ \\ Guohua Cao, ${ }^{9}$ Bruce S. Lieberman, ${ }^{10}$ Sally P. Leys, ${ }^{11}$ and Shuhai Xiao ${ }^{1}$ \\ ${ }^{1}$ Department of Geosciences, Virginia Tech, Blacksburg, Virginia 24061, USA <qingt@ vt.edu>, <xiao@vt.edu> \\ ${ }^{2}$ CNPC International (Chad) Co. Ltd., N'djamena, Chad <hujie@ cnpcic.com> \\ ${ }^{3}$ Institute of Exploration, Development and Research of PetroChina Company Limited Changqing Oilfield Branch, Xi'an 710018, China \\ $<$ xguwei_cq@petrochina.com.cn> \\ ${ }^{4}$ National Engineering Laboratory for Exploration and Development of Low-permeability Oil \& Gas Fields, Xi' an 710018, China \\ ${ }^{5}$ Department of Geology, Northwest University, Xi' an 710069, China \\ ${ }^{6}$ State Key Laboratory of Palaeobiology and Stratigraphy, Center for Excellence in Life and Paleoenvironment, Nanjing Institute of Geology \\ and Palaeontology, Chinese Academy of Sciences, Nanjing, 210008, China <xlyuan@ nigpas.ac.cn>, <binwan@nigpas.ac.cn> \\ ${ }^{7}$ University of Chinese Academy of Sciences, Beijing 100039, China \\ ${ }^{8}$ CAS Key Laboratory of Economic Stratigraphy and Palaeogeography, Nanjing Institute of Geology and Palaeontology, Chinese Academy \\ of Sciences, Nanjing 210008, China <cmzhou@ nigpas.ac.cn> \\ ${ }^{9}$ Virginia Tech-Wake Forest University School of Biomedical Engineering and Sciences, Virginia Tech, Blacksburg, Virginia 24061, USA \\ $<$ xu14@vt.edu>,<ghcao@vt.edu> \\ ${ }^{10}$ Department of Ecology \& Evolutionary Biology, University of Kansas, Lawrence, Kansas 66045, USA <blieber@ku.edu> \\ ${ }^{11}$ Department of Biological Sciences, University of Alberta, Edmonton, AB T6G 2E9, Canada <sleys@ @ulberta.ca>
}

\begin{abstract}
The lower-middle Hetang Formation (Cambrian Stage 2-3) deposited in slope-basinal facies in South China is well known for its preservation of the earliest articulated sponge fossils, providing an important taphonomic window into the Cambrian Explosion. However, the Hetang Formation also hosts a number of problematic animal fossils that have not been systematically described. This omission results in an incomplete picture of the Hetang biota and limits its contribution to the understanding of the early evolution of animals. Here we describe a new animal taxon, Cambrowania ovata Tang and Xiao, new genus new species, from the middle Hetang Formation in the Lantian area of southern Anhui Province, South China. Specimens are preserved as carbonaceous compressions, although some are secondarily mineralized. A comprehensive analysis using reflected light microscopy, scanning electron microscopy, energy-dispersive X-ray spectroscopy, and micro-CT reveals that the new species is characterized by a spheroidal to fusoidal truss-like structure consisting of rafter-like crossbars, some of which are secondarily baritized and may have been internally hollow. Some specimens have aperture-like structures that are broadly similar to oscula of sponges, whereas others show evidence of a medial split reminiscent of gaping carapaces. While the phylogenetic affinity of Cambrowania ovata Tang and Xiao, n. gen. n. sp. remains problematic, we propose that it may represent carapaces of bivalved arthropods or more likely sponges in early life stages. Along with other problematic metazoan fossils such as hyolithids and sphenothallids, Cambrowania ovata Tang and Xiao, n. gen. n. sp. adds to the diversity of the sponge-dominated Hetang biota in an early Cambrian deepwater slope-basinal environment.
\end{abstract}

UUID: http://zoobank.org/44de9472-7e3f-42d1-9554-7b3434df91d9

\section{Introduction}

The Cambrian Explosion marks the most important biodiversification event in Earth history (Erwin and Valentine, 2013). All major animal body plans appeared in the fossil record during this biodiversification event, setting the stage for the evolution of modern animal phyla (Knoll and Carroll, 1999; Erwin et al., 2011). Recently, our understanding of the Cambrian Explosion has been significantly improved, in large part due to systematic studies of various exceptionally preserved fossil assemblages or Konservat-Lagerstätten from the early-middle Cambrian Period, including the Sirius Passet, Chengjiang, Guanshan, Emu
Bay Shale, Kaili, and Burgess Shale biotas (Holmes et al., 2018). One of the early Cambrian Lagerstätten that has yet to be brought under the spotlight is the Hetang biota, which occurs in deepwater black shales of the lower-middle Hetang Formation in southern Anhui Province of South China (Fig. 1). The Hetang biota is dominated by sponge fossils and contains some of the earliest articulated sponges, particularly abundant in a unit of highly organic-rich and combustible mudstone (known locally as the stone coal unit) in the lower Hetang Formation (Hu et al., 2002; Yuan et al., 2002; Chen et al., 2004; Wu et al., 2005; Xiao et al., 2005; Botting et al., 2012; Botting et al., 2014). However, other macrofossils in the Hetang Formation 

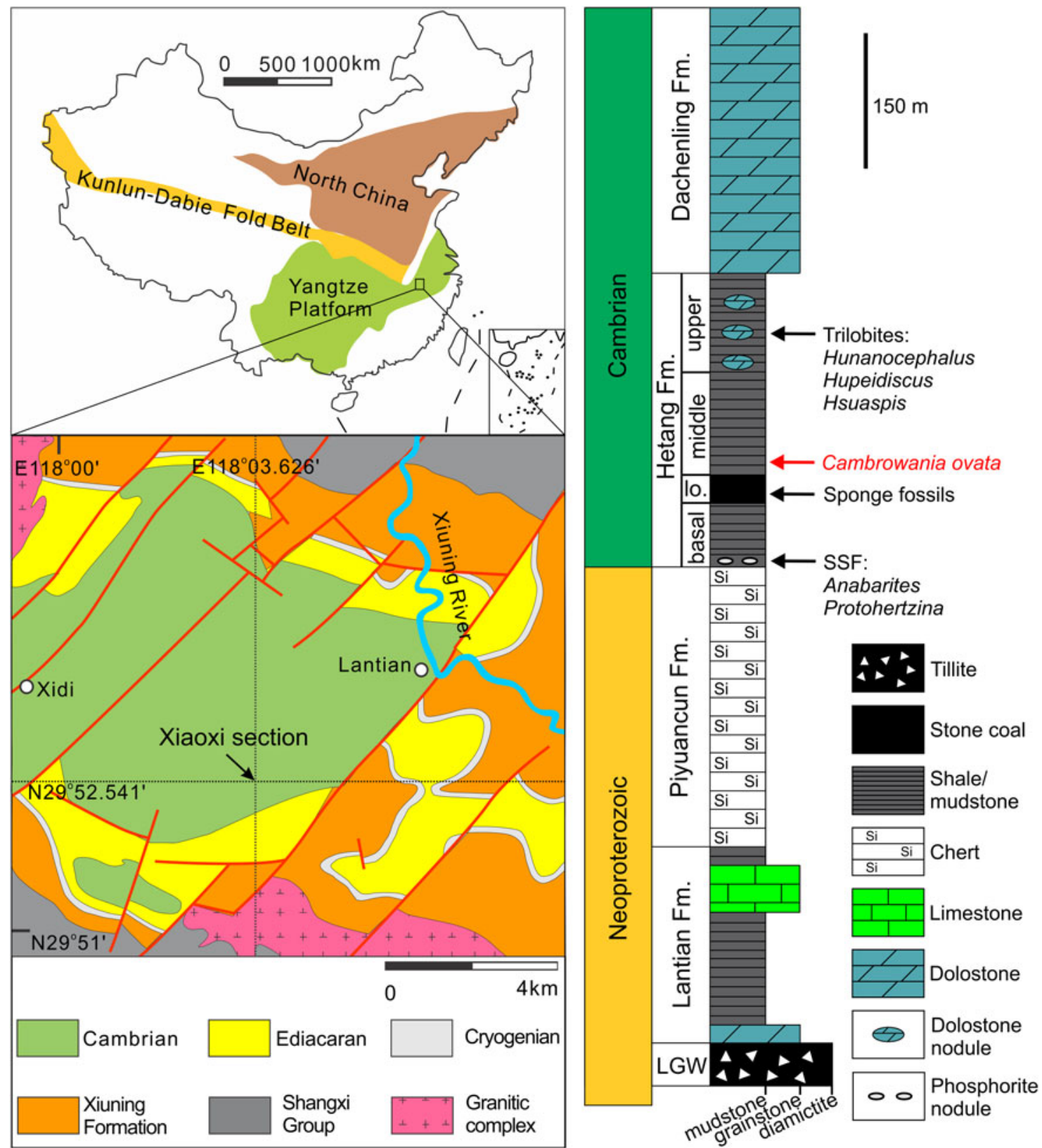

Figure 1. Geological map and stratigraphic column of the Neoproterozoic-lower Cambrian succession in the Lantian area of southern Anhui Province in South China. lo. = lower; LGW = Leigongwu Formation; Fm. = formation; SSF = small shelly fossils.

are either poorly illustrated or largely ignored in previous studies (Yuan et al., 2002; Chen et al., 2004). To more fully document the diversity of the Hetang biota, we describe a new group of problematic animal fossils from black shale/mudstone of the middle Hetang Formation (Cambrian Stage 2-3) in the Lantian area of South China. The fossils, described as a new taxon, Cambrowania ovata Tang and Xiao, new genus new species, may represent either the carapace of bivalved arthropods or early life stages of sponges.

\section{Geological setting}

The Hetang Formation is mainly distributed in southern Anhui and neighboring northern Jiangxi and western Zhejiang provinces.
It can be traced with relative ease in these areas, although its stratigraphic thickness may vary in places (Xue and Yu, 1979). In this study, we focus on the Lantian area of southern Anhui Province where the Hetang Formation overlies siliceous rock of the largely terminal Ediacaran Piyuancun Formation and underlies the early Cambrian limestone of the Dachenling Formation (Fig. 1). Regionally, the Hetang Formation is $318 \mathrm{~m}$ in maximum thickness. It can be subdivided into four lithostratigraphic units. The basal unit is a $\sim 68 \mathrm{~m}$ thick siliceous-carbonaceous mudstone rich in phosphorite nodules at the base. Overlying this basal unit are, in ascending stratigraphic order, the lower unit of $\sim 30 \mathrm{~m}$ thick stone coal (combustible organic-rich mudstone), the middle unit of $\sim 110 \mathrm{~m}$ thick siliceous-carbonaceous mudstone and shale, and the upper unit of $\sim 110 \mathrm{~m}$ thick carbonaceous shale with 

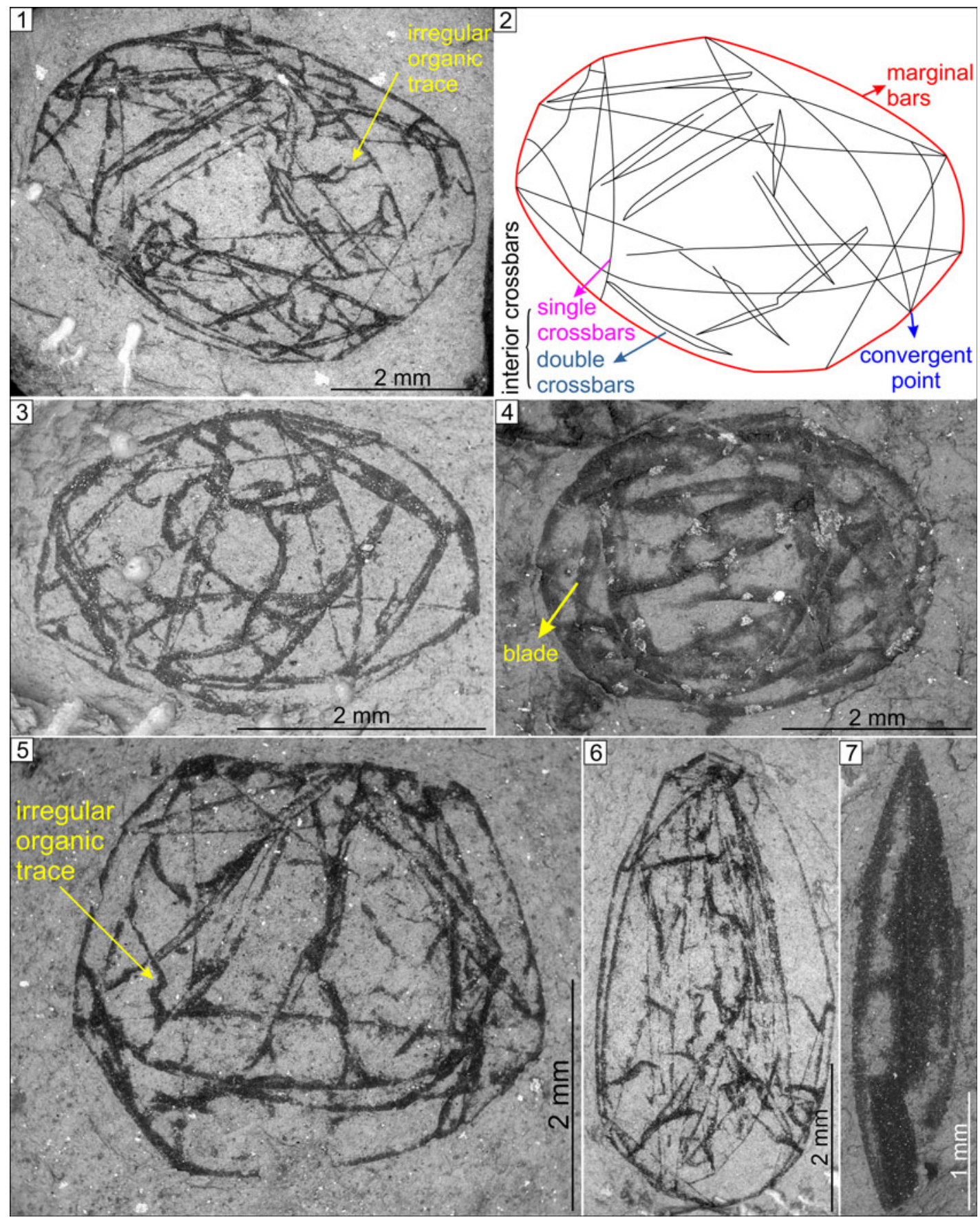

Figure 2. Cambrowania ovata Tang and Xiao, n. gen. n. sp. from the middle Hetang Formation. (1) Holotype, HT-T8-9V-25, VPIGM-4729. (2) Schematic sketch of specimen in (1), highlighting the marginal crossbars, interior crossbars (e.g., single crossbars and double crossbars), and convergent point. (3-7) HT-T5-46-1, VPIGM-4730; HT-T8-12-3, VPIGM-4731; HT-T8-10-3, VPIGM-472; HT-T5-17-1, VPIGM-4733; and HT-T8-1V-1V, VPIGM-4734, respectively. All fossil images are backscattered electron scanning electron microscopy (BSE-SEM) photographs unless otherwise noted. Field collection numbers (prefix HT-) and museum catalog numbers (prefix VPIGM-) are given for each illustrated specimen.

carbonate nodules. It should be noted that there are variations in the literature with regard to the lithostratigraphic boundary between the Piyuancun and Hetang formations: (1) some authors place the boundary just above the phosphorite nodule bed of the basal unit (Yue and $\mathrm{He}, 1989$; $\mathrm{He}$ and $\mathrm{Yu}, 1992$; Yue and Zhao, 1993; Xiao et al., 2005); (2) Xiang et al. (2017) place the boundary at about $150 \mathrm{~m}$ below the stone coal unit; and (3) in regional geological survey reports (Bureau of Geology and Mineral Resources of Anhui Province, 1987) and in more recent literature (Steiner et al., 2007; Dong et al., 2012), the PiyuancunHetang boundary is placed at the base of the phosphorite nodule bed. In this paper we follow the latter stratigraphic treatment, in which the Ediacaran-Cambrian boundary is at or near the Piyuancun-Hetang boundary (contra Xiang et al., 2017) because the Piyuancun Formation contains typical terminal Ediacaran fossils whereas the phosphorite nodule bed contains basal Cambrian small shelly fossils (Dong et al., 2012). Sedimentological and geochemical data suggest that the Hetang Formation was mainly 


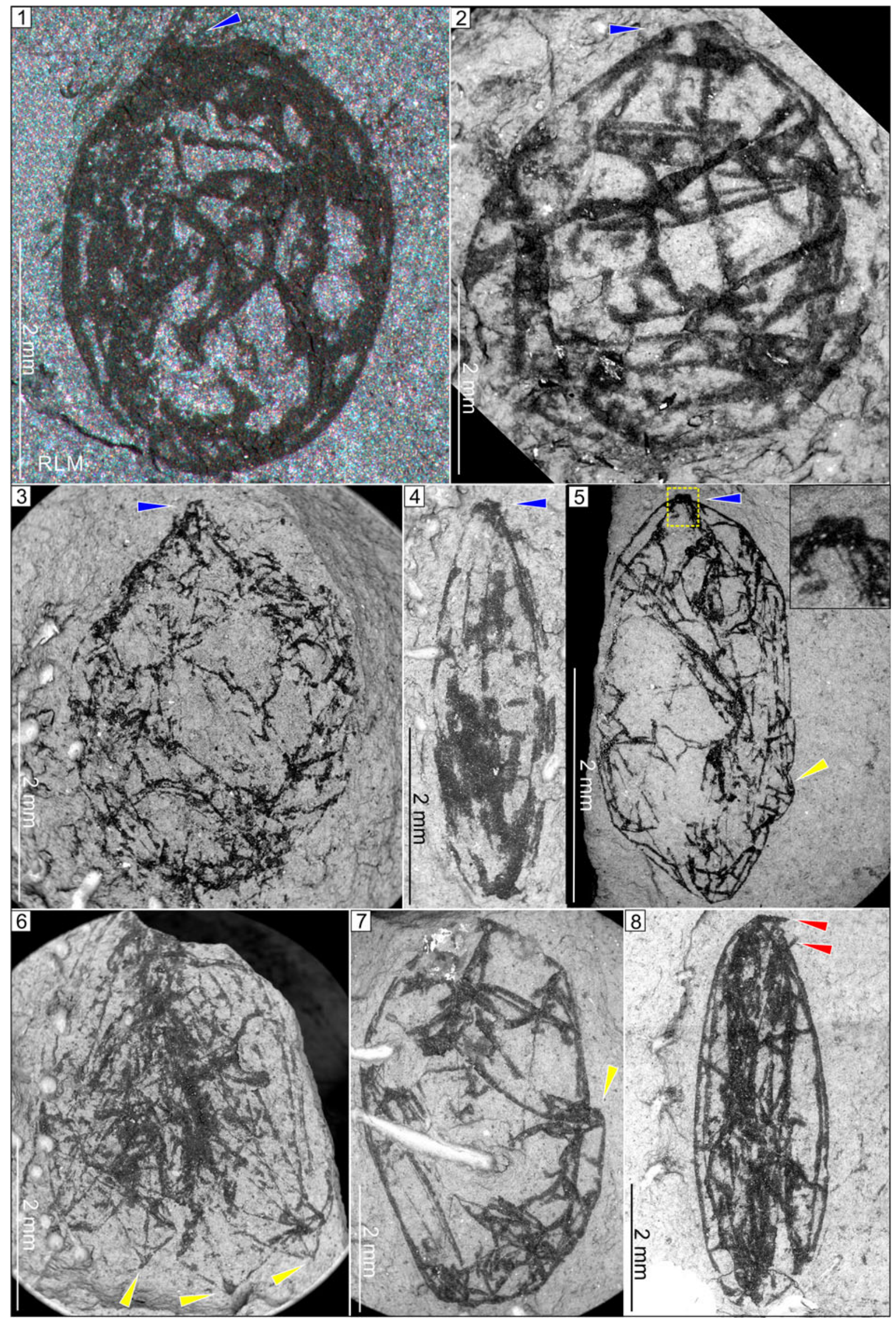


deposited in a ferruginous slope-basinal environment (Zhou and Jiang, 2009; Yuan et al., 2014; Xiang et al., 2017).

The Hetang Formation contains abundant fossils that are biostratigraphically informative. Regionally, phosphorite in the basal unit contains small shelly fossils such as Anabarites trisulcatus Missarzhevsky in Voronova and Missarzhevsky, 1969, Protohertzina anabarica Missarzhevsky, 1973, and Kaiyangites novilis Qian and Yin, 1984 (Yue and He, 1989; He and Yu, 1992; Yue and Zhao, 1993; Steiner et al., 2003), but no Cloudina or Sinotubulites. Although rare specimens of Anabarites and Protohertzina have been reported from the terminal Ediacaran Period (Zhu et al., 2017; Cai et al., 2019), the absence of Cloudina or Sinotubulites and the presence of Kaiyangites novilis indicate that the small shelly fossils from the Hetang Formation are characteristic of the basal Cambrian Anabarites trisulcatus-Protohertzina anabarica Assemblage Zone (Yao et al., 2005; Steiner et al., 2007). In other words, the basal unit is likely Cambrian Fortunian in age. The stone coal in the lower unit contains abundant articulated sponge fossils (Xiao et al., 2005). Regional litho- and biostratigraphic correlation of the Hetang Formation in southern Anhui and western Zhejiang provinces indicates the lower unit or the stone coal unit may be Cambrian Stage 2 (Xiao et al., 2005). Carbonate nodules in the upper unit in western Zhejiang Province yield trilobites such as Hunanocephalus, Hupeidiscus, and Hsuaspis ( $\mathrm{Li}$ et al., 1990; $\mathrm{He}$ and $\mathrm{Yu}, 1992)$, which are indicative of Cambrian Stage 3 (Peng et al., 2012). Therefore, the age of the carbonaceous mudstone and shale of the middle unit, from which the fossils reported in this paper were collected, is probably somewhere between Cambrian Stage 2 and Stage 3, with the ambiguity related to the uncertainty of the first appearance datum of trilobites in the Hetang Formation.

\section{Materials and methods}

In total, 436 specimens of Cambrowania ovata Tang and Xiao, n. gen. n. sp. were recovered from mudstone/shales of the middle Hetang Formation (Fig. 1). The majority of the specimens are preserved as carbonaceous compressions, although some are secondarily mineralized. All specimens were initially examined with reflected light microscopy (RLM) using an Olympus SZX7 stereomicroscope connected with an Infinity 1 camera. Wellpreserved specimens were subsequently examined using backscattered electron scanning electron microscopy (BSE-SEM), secondary electron scanning electron microscopy (SE-SEM), and energy-dispersive X-ray spectroscopy (EDS) on an FEI Quanta 600FEG environmental SEM coupled with a Bruker EDX with a silicon-drifted detector (Muscente and Xiao, 2015). The operating voltage in BSE-SEM, SE-SEM, and
EDS modes was 5-20 kV in high-vacuum condition. Selected specimens with mineralized structures were scanned using an Xradia micro-CT to visualize internal structures. The $\mathrm{X}$-ray source for the micro-CT scanning was operated at $90 \mathrm{kV}$ and $88 \mu \mathrm{A}$ with a flat area detector. The detector has a resolution of 2,048 $\times 2,048$ pixels; each pixel size is $0.05 \mathrm{~mm} \times 0.05 \mathrm{~mm}$. The scanned sample was placed in the middle between the $\mathrm{X}$-ray source and the detector. The source-object and source-detector distances were $25 \mathrm{~mm}$ and $155 \mathrm{~mm}$, respectively. Under such geometric setting, the generated micro-CT images have a matrix size of $2,048 \times 2,048$ with the voxel size $4.40 \mu \mathrm{m} \times$ $4.40 \mu \mathrm{m}$.

Repository and institutional abbreviation.-Types, figured, and other specimens examined in this study are reposited at Virginia Polytechnic Institute Geosciences Museum (VPIGM), Blacksburg, Virginia, USA.

\section{Systematic paleontology}

Phylum, Class, Order, Family incertae sedis Genus Cambrowania Tang and Xiao, new genus

Type species.-Cambrowania ovata Tang and Xiao, n. gen. n. sp.; by present designation; by monotypy.

Diagnosis. - Spheroidal, ovoidal, or fusoidal truss-like fossils consisting of organic-rich, rafter-like crossbars or blades. The crossbars are nearly straight or slightly curved, singularly or doubly arranged, originally cylindrical and perhaps internally hollow, and interlaced to form a network-like truss. A terminal aperture may be developed.

Occurrence.-Specimens were recovered from shale and mudstone of the middle Hetang Formation (Stage 2-3, lower Cambrian) in the Lantian area, South China.

Etymology.-The genus name is derived from Cambrian and Wan (Anhui Province), referring to the stratigraphic and geographic occurrence of the type species.

Remarks.-Cambrowania Tang and Xiao, n. gen. is distinguished from other known fossils of the early Cambrian Period, such as radiolarians (Braun et al., 2007), the scyphozoan Olivooides (Dong et al., 2013), and any known bivalved arthropods (Steiner et al., 2003), by its spheroidal truss-like body plan with rafter-like crossbars that are cylindrical and internally hollow.

Cambrowania ovata Tang and Xiao, new species Figures 2-6

\footnotetext{
Figure 3. Cambrowania ovata with aperture-like structures, outgrowths, and crossbars that protrude beyond the margin of the fossils. (1-5) Specimens with aperture-like structures (blue arrowheads). HT-T8-9V-8V, VPIGM-4735; HT-T8-25-6, VPIGM-4736; HT-T7-55-1,VPIGM-4737; HT-4-35-1, VPIGM-4738; and HT-T5-55-1, VPIGM-4739, respectively. Inset image in (5) is a close-up view of the aperture-like structure (blue arrowhead and rectangle). Yellow arrowhead marks an outgrowth structure. $(\mathbf{6}, 7)$ Specimens with outgrowths (yellow arrowheads) consisting of marginally converging crossbars. HT-T6-58-1, VPIGM-4740 and HT-T8-3-3, VPIGM-4741, respectively. (8) Specimen with crossbars protruding beyond the margin of the fossil (red arrowhead). HT-T4-10-1, VPIGM-4742. RLM $=$ reflected light microscopy photograph. All fossil images are backscattered electron scanning electron microscopy (BSE-SEM) photographs unless otherwise noted. Field collection numbers (prefix HT-) and museum catalog numbers (prefix VPIGM-) are given for each illustrated specimen.
} 
Holotype.-HT-T8-9V-25, illustrated in Figure 2.1, reposited at Virginia Polytechnic Institute Geosciences Museum (catalog number VPIGM-4729).

Paratype.-HT-T3-8-1, illustrated in Figure 5.3, reposited at Virginia Polytechnic Institute Geosciences Museum (catalog number VPIGM-4747).

Diagnosis. - A species of Cambrowania with the maximum dimension in millimeter scale.

Occurrence.-Shale/mudstone of the middle Hetang Formation in the Lantian area, South China.

Morphological description.-Fossils are preserved as discoidal (Fig. 2.1-2.4), subpolygonal (Fig. 2.5), oval to elliptical (Fig. 2.6), and fusiform (Fig. 2.7) carbonaceous compressions that are $1.7-10.7 \mathrm{~mm}$ in maximum dimension. Main structures of the fossil include marginal bars defining the outline of the fossil and interior crossbars contained within the fossil (Fig. 2.2). Interior crossbars typically terminate at the margin of the fossil. Multiple interior crossbars can terminally converge at a point on the margin to form a cluster of radiating crossbars (Fig. 2.1-2.3, 2.5). Double crossbars consist of two crossbars that are subparallel and, in some cases, terminally convergent (Fig. 2.1-2.3). Crossbars are 15$94 \mu \mathrm{m}$ in width and $1-6 \mathrm{~mm}$ in length, with broader ones forming blades (Fig. 2.4). Crossbars of different widths can be present in the same specimen (Figs. 2.1, 2.3). Most crossbars are straight (Figs. 2.1, 2.3, 2.5), although some are curved (Fig. 2.3, 2.4) and even twisted (Fig. 2.1, 2.3, 2.5). When the marginal bars are straight, the fossils typically have a polygonal outline (Fig. 2.5).

Some compressed specimens appear to have an aperturelike structure. This structure can be a subtle indentation (Fig. 3.1) or a protrusion (Fig. 3.2-3.5) at one end of the fossil, with the opposite end being round (Fig. 3.1-3.3) or tapered (Fig. 3.5). The aperture, $0.2-0.6 \mathrm{~mm}$ in width, gradually transitions to the main body of the fossil (Fig. 3.1-3.4), without a clearly defined boundary such as a constriction. It is possible that the terminal aperture was present in all specimens of Cambrowania ovata but only visible in laterally compressed specimens. Subround to triangular outgrowths, which appear to have developed from convergent points that protruded beyond the margin of the fossils (Fig. 3.5-3.7), are present in some specimens. Occasionally, individual crossbars are found protruding beyond the margin of the fossil (Fig. 3.8).

In addition, a few specimens in our collection (four out of 436 specimens) preserve a medial split (Fig. 4.1, 4.2) that is reminiscent of the ventral margin of the carapace of bivalved arthropods (e.g., Hou and Bergström, 1997, fig. 20). This split results in a V-shaped cleft, with two hemispherical halves connected on one side and gaping on the other. The gaping margin of the hemispherical halves is defined by marginal crossbars, and apparently no crossbars reach beyond the margin (Fig. 4.1, 4.2), indicating that the medial split may be a biological rather than a taphonomic structure. The gaping angle is $14^{\circ}$ to $67^{\circ}$, and butterflied configuration (i.e., gaping angle of $180^{\circ}$; Briggs et al., 2015) is not seen. Some specimens that do not show a
V-shaped cleft appear to have slightly offset margins (e.g., Fig. 4.3, 4.4). It is possible that specimens with V-shaped clefts (e.g., Fig. 4.1, 4.2) and those with slightly offset margins represent taphonomic variants (cf. lateral versus anteriorposterior compression of bivalved arthropod carapace with gaping margins).

Taphonomic description.-The crossbars are mostly preserved as two-dimensional carbonaceous compressions, with a few exceptions where they are secondarily mineralized in three dimensions. Abundant pyrite framboids and their molds are present in the crossbars (Fig. 5.1, 5.2), indicating organic degradation through sulfate reduction. The carbonaceous nature of the crossbars is confirmed in EDS point analysis and elemental maps. EDS point analyses show high carbon (C) and oxygen $(\mathrm{O})$ peaks and low sulfur $(\mathrm{S})$, aluminum $(\mathrm{Al})$, and silicon ( $\mathrm{Si}$ ) peaks (Fig. 5.3-5.6), indicating the crossbars mainly consist of organic material. EDS elemental maps confirm the enrichment of $\mathrm{C}$ and deficiency of $\mathrm{S}, \mathrm{Ca}, \mathrm{Al}$, and $\mathrm{Si}$ in the crossbars relative to the matrix (Fig. 5.7).

One secondarily mineralized fusoidal specimen has been analyzed in detail (Fig. 6). This specimen is partially covered with a thin barite layer, which is confirmed by BSE-SEM images and elemental maps (Fig. 6.2, 6.9). In cross sections perpendicular to the bedding plane, the barite layer is $10-16 \mu \mathrm{m}$ in thickness (Fig. 6.3, 6.4). A cluster of marginally converging crossbars occurs at one end of the fusoidal specimen (Fig. 6.5, 6.6), reminiscent of a hexactine-based sponge spicule. It is possible that another cluster occurs at the opposite end, but the crossbars are exfoliated, and only vague imprints are visible (Fig. 6.1). The crossbars are three-dimensionally replicated by barite, and this is clearly seen in a large crossbar running between the two apices of the fusoidal fossil (Fig. 6.1). In transverse cross sections, the baritized crossbars are internally hollow with centripetally growing barite crystals and slightly compressed with a maximum diameter of 180-208 $\mu \mathrm{m}$ (Fig. 6.3, $6.4,6.7,6.8)$.

Etymology.-The species epithet is derived from Latin ovatus, referring to the fusoidal to ovoidal shape of this species.

Materials._A total of 436 specimens from shale/mudstone of the middle Hetang Formation.

Remarks. - Cambrowania ovata Tang and Xiao, n. gen. n. sp. is morphologically similar to the problematic fossil Chuaria circularis Walcott, 1899 (Tang et al., 2017) and the carapaces of the bivalved arthropod Iosuperstes collisionis (Briggs et al., 2015). However, neither of these species has rafter-like crossbars that are interlaced to form a network-like truss, which is the main character of Cambrowania ovata.

\section{Discussion}

Morphological reconstruction.-Although specimens of Cambrowania ovata are mostly preserved as carbonaceous compressions, three-dimensionally baritized specimens (Fig. 6) indicate that the species was not a flattened organism when alive. Crossbars that radiate from a convergent point are 

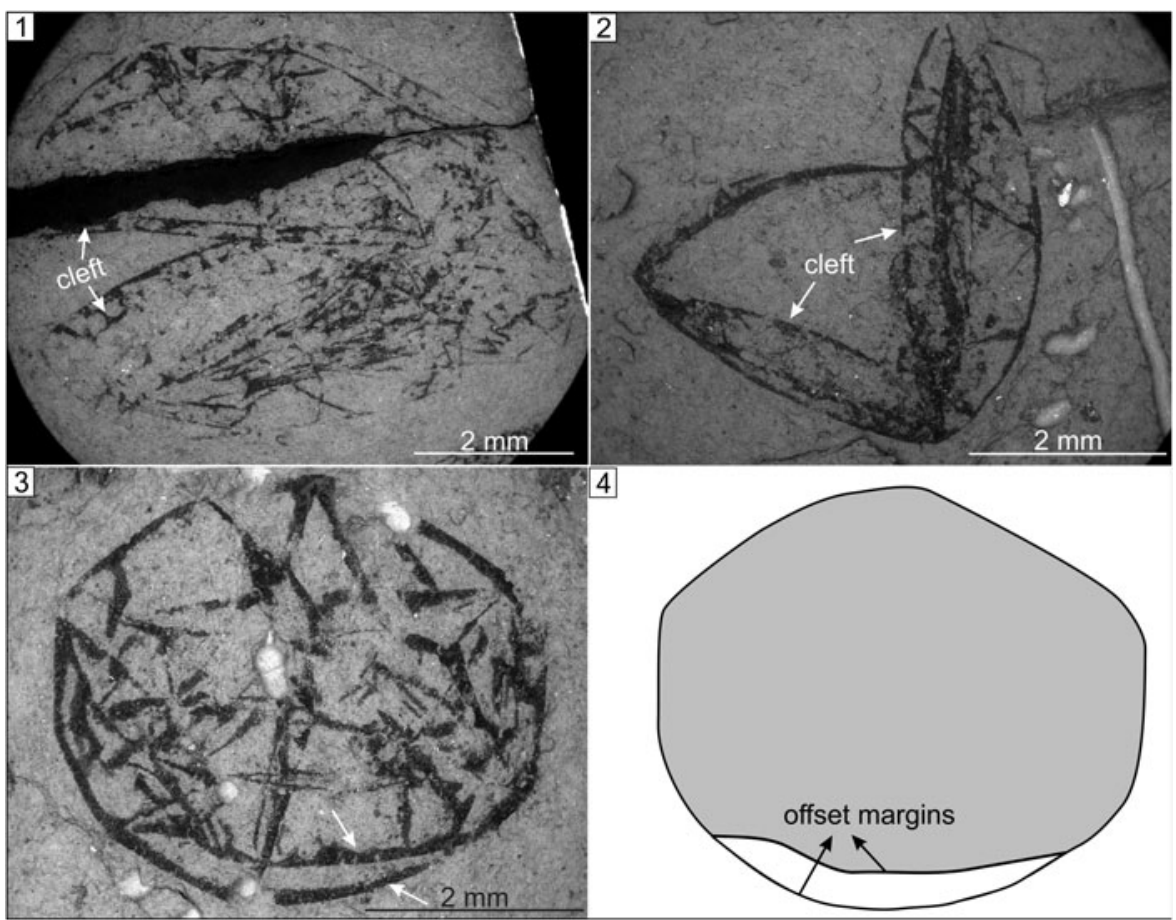

Figure 4. Cambrowania ovata with V-shaped clefts or offset margins. (1-3) HT-T5-23-1, VPIGM-4743; HT-T8-2-1, VPIGM-4744; and HT-T8-1V-7, VPIGM-4745, respectively. (4) Schematic sketch of specimen illustrated in (3). Arrows denote V-shaped clefts or offset margins. All fossil images are backscattered electron scanning electron microscopy (BSE-SEM) photographs unless otherwise noted. Field collection numbers (prefix HT-) and museum catalog numbers (prefix VPIGM-) are given for each illustrated specimen.
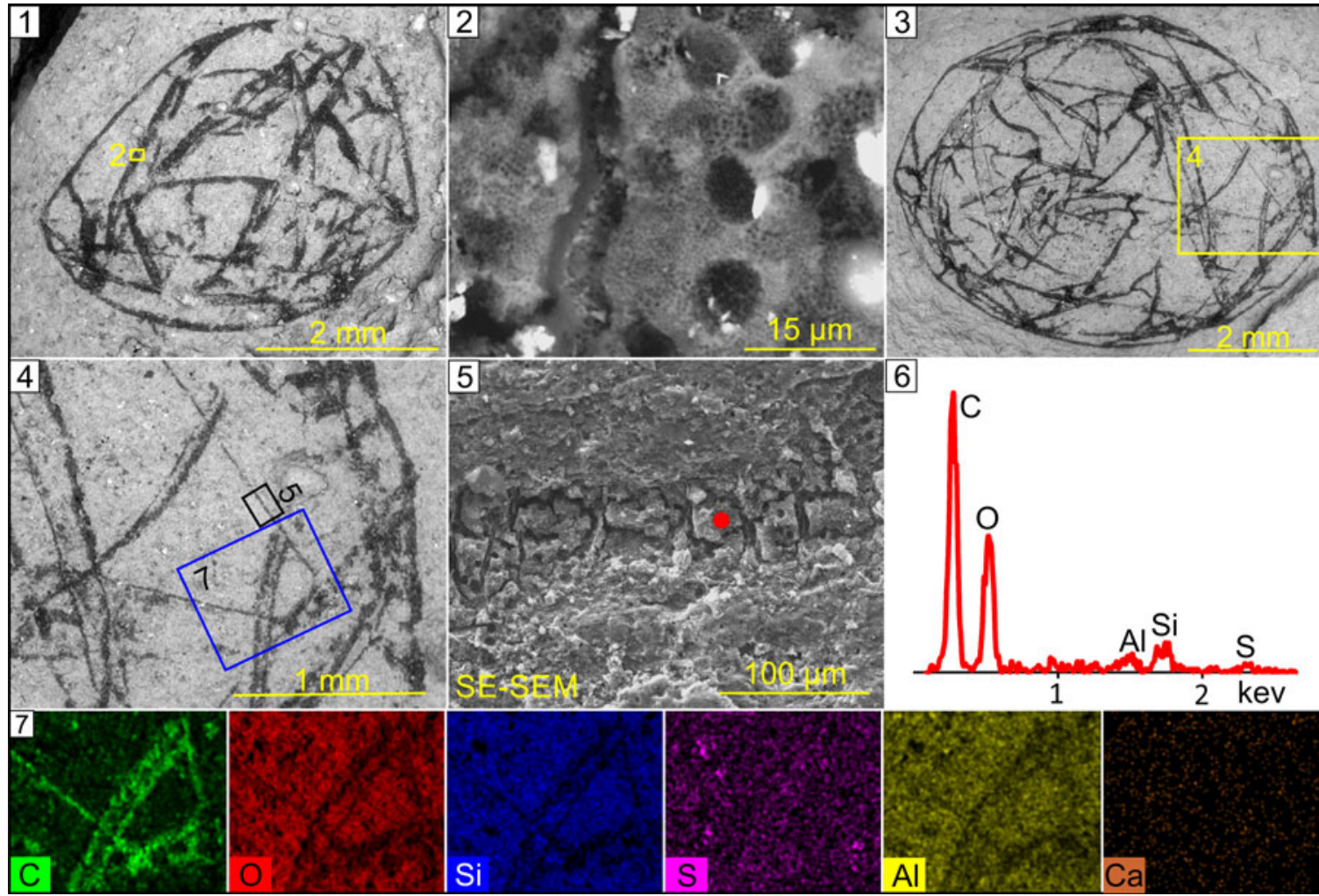

Figure 5. Taphonomy of Cambrowania ovata, with evidence for carbonaceous preservation and pyrite formation. (1) HT-T4-11-1, VPIGM-4746. (2) Close-up view of rectangle in (1), showing molds of pyrite framboids. (3) Paratype, HT-T3-8-1, VPIGM-4747. (4) Close-up view of rectangle in (3), showing crossbars of different widths. (5) Close-up view of black rectangle in (4). (6) Energy-dispersive X-ray spectroscopy (EDS) point analysis at location marked by red circle in (5). (7) EDS elemental maps of blue rectangle in (4). Elements labeled in lower left. SE-SEM = secondary electron scanning electron microscopy photograph. All fossil images are backscattered electron scanning electron microscopy (BSE-SEM) photographs unless otherwise noted. Field collection numbers (prefix HT-) and museum catalog numbers (prefix VPIGM-) are given for each illustrated specimen. 

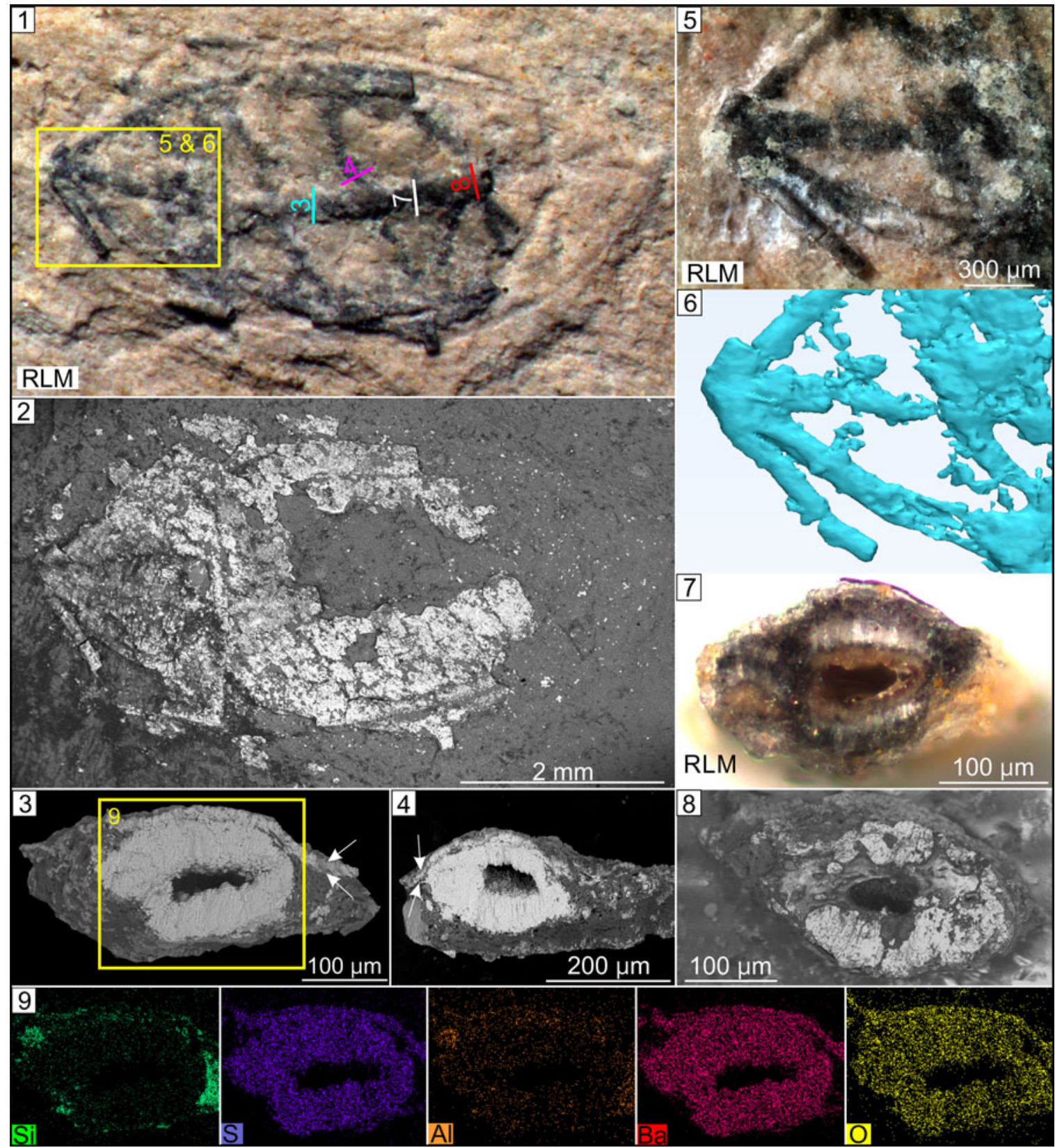

Figure 6. Taphonomy of Cambrowania ovata, with evidence for secondary baritization. (1, 2) HT-T7-30-1, VPIGM-4748, RLM and BSE-SEM photographs, respectively, of the same baritized specimen. Bright area in (2) shows where barite is present. Note that the central part of the specimen [area marked as 3, 4, 7, 8 in (1)] was removed after RLM (1) and before BSE-SEM (2), hence a window of no barite in (2). $(\mathbf{3 , 4 , 7 , 8 )}$ Cross-sectional view of crossbars removed from marked and labeled positions in (1), showing baritized crossbars and a thin layer of barite [bracketed by white arrows in (3) and (4)] that covers the entire fossil. (5) Close-up view of yellow rectangle in (1). (6) Micro-CT reconstruction of radiating crossbars shown in (5). (9) EDS elemental maps of rectangle in (3), with elements marked in lower left. RLM = reflected light microscopy photograph. All fossil images are backscattered electron scanning electron microscopy (BSE-SEM) photographs unless otherwise noted. Field collection numbers (prefix HT-) and museum catalog numbers (prefix VPIGM-) are given for each illustrated specimen.

reminiscent of hexactine-based spicules of glass sponges in early ontogenetic stages or of single-rayed oxeas (Fig. 7.1, 7.2); these 'spicules' can project beyond the margin of the organism in $C$. ovata (Fig. 4.8) just as spicules can in modern sponges (Fig. 7.1, 7.2). At least one possible 'spicule' is reminiscent of hexactine-based spicules (Fig. 6.1, 6.2, 6.5, 6.6). In addition, the aperture-like structure of Cambrowania ovata is somewhat similar to the osculum of sponges (Fig. 7.3, 7.4). If we interpret these features as spicules and oscula, then we would reconstruct Cambrowania ovata as a spheroidal or ovoidal organism that is similar to the postlarval juveniles of the hexactinellid sponge Oopsacas minuta Topsent, 1927 (Fig. 7; Leys et al., 2016). Alternatively, considering that a few specimens in our collection are preserved with a V-shaped cleft (Fig. 4.1, 4.2) or offset margins (Fig. 4.3, 4.4), Cambrowania ovata may be interpreted as a bivalved organism housed within a carapace similar to those of bivalved arthropods (Briggs et al., 2015). Mitigating against the arthropod affinity is the fact that only a very small number of specimens have a V-shaped cleft, and thus we cannot completely rule out the possibility that this 


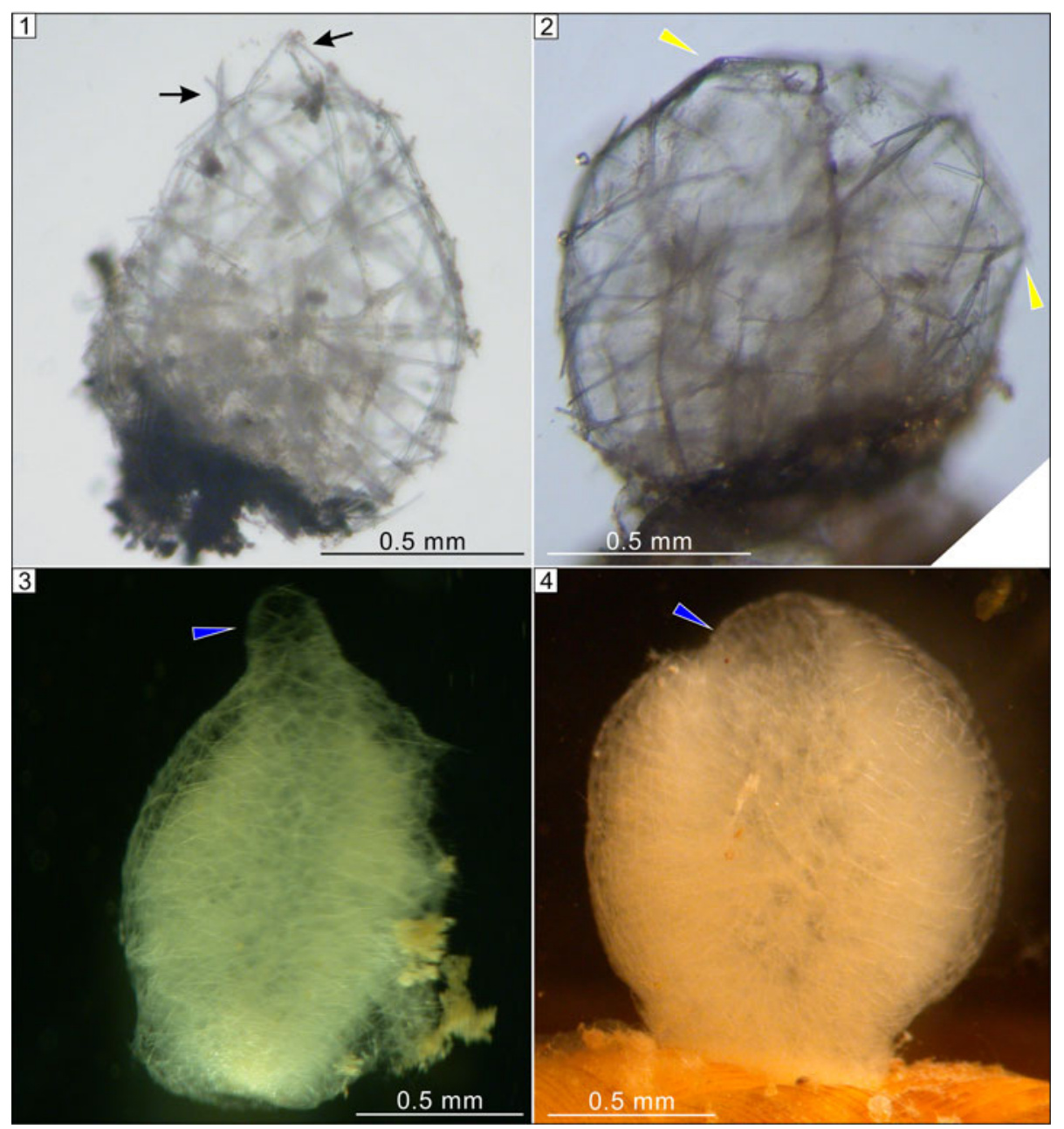

Figure 7. Extant hexactinellid sponge Oopsacas minuta in early life history stages. $(\mathbf{1}, \mathbf{2})$ Spheroidal stage of metamorphosis with protruding spicules $($ black arrows) and a polygonal outline (yellow arrowheads). $(3,4)$ Juvenile stage with either a raised or a depressed osculum (blue arrowheads).

structure may be a taphonomic artifact (e.g., rupture along crossbars). Therefore, we tentatively favor the spheroidal or ovoidal reconstruction and the sponge affinity over the bivalved reconstruction and the arthropod affinity.

Biological interpretation.-Although Cambrowania ovata is superficially similar to some algal fossils (e.g., Chuaria) in having spheroidal morphology and organic-rich composition, we are unaware of any algae, fossil or extant, that have hollow cylindrical crossbars similar to those in Cambrowania ovata. In addition, Cambrowania ovata superficially resembles some Cambrian radiolarians (Dong et al., 1997). Indeed, putative radiolarians have been reported from the basal unit of the Hetang Formation (Braun et al., 2007). However, Cambrowania ovata is more than an order of magnitude larger than these Cambrian radiolarians, and it does not have the spherical lattice with radiating spines characteristic of radiolarians. Thus, the following discussion is focused on the possible animal affinities of Cambrowania ovata.

The V-shaped cleft invites a tentative comparison between Cambrowania ovata and bivalved arthropods. Specimens with a V-shaped cleft may represent carapaces of bivalved arthropods, but these bivalved carapaces probably had limited gaping, given the lack of any butterflied specimens in our collection. The strongly irregular traces of organic matter (yellow arrows in Fig. 2.1, 2.5) could be crumples or wrinkles on a flexible carapace due to taphonomic compaction, which are common in high-relief carapaces of arthropods (Fu and Zhang, 2011; Briggs et al., 2015). However, the straight and gently curved crossbars of Cambrowania ovata would then likely represent thickened ribs that are structural components of the organism, particularly if their hollow and cylindrical nature, as shown in baritized specimens (Fig. 6), is confirmed in the future.

The crossbars of Cambrowania ovata may represent ornaments (e.g., thickened ribs or ridges) of bivalved carapaces. Many Paleozoic bivalved arthropods have various ornaments on their carapaces, such as reticulate ornaments on the carapace of Tuzoia (Vannier et al., 2007), striated ornaments on the carapace of Isoxys (Fu et al., 2009), and pits on the carapace of Iosuperstes (Briggs et al., 2015). It is acknowledged that these ornaments are morphologically distinct from the crossbars of Cambrowania ovata, but in principle, thickened ribs or ridges are not unimaginable as carapace ornaments. Indeed, some extant crustaceans can develop reticulate ornaments on their carapaces, with cylindrical ridges somewhat similar to the crossbars of Cambrowania ovata. Polycope reticulata Müller, 1894, for 
example, develops reticulate sculptures with cylindrical ridges forming primary polygonal ornamentation on its carapace (Vannier et al., 2007).

However, the majority of Cambrowania ovata specimens do not have any trace of a V-shaped cleft, casting doubts on the interpretation of Cambrowania ovata as carapaces of bivalved arthropods. More important, the carapace interpretation is incompatible with many specimens that have a polygonal morphology (Fig. 2.5), an aperture-like structure (Fig. 3.1-3.5), and sharp outgrowths (Fig. 3.5-3.7).

Considering the possible presence of an osculum (Fig. 3.13.5) and the morphological similarity between the clustered crossbars and hexactine-based sponge spicules such as pentactines (e.g., those in Sanshapentella dapingi Xiao et al., 2005), it is tempting to consider Cambrowania ovata a spheroidal sponge. Although extant sponge spicules are usually biomineralized (either siliceous or calcareous), some modern demosponges have only organic skeletons (de Cook and Bergquist, 2002; Hill et al., 2013). In addition, many fossil sponges have weakly biomineralized or entirely organic skeletons; these include the demosponge Vauxia (Ehrlich et al., 2013) and some protomonaxonids such as piraniids and chancelloriids (Botting and Muir, 2018). Thus, the largely organic composition of the crossbars does not necessarily exclude a sponge interpretation for Cambrowania ovata. Intriguingly, although adult sponges typically have tubular bodies, sponge juveniles tend to be spheroidal in shape. For example, the hexactinellid sponge Oopsacas minuta in the metamorphosis stage is broadly spheroidal with a polygonal outline (Fig. 7.2; Leys et al., 2016) and subsequently develops an osculum in the juvenile stage (Fig. 7.3, 7.4; Leys et al., 2016). The comparison with juvenile sponges is further supported by the presence of a putative osculum in some specimens of Cambrowania ovata (Fig. 3.1-3.5). The V-shaped cleft in a few Cambrowania ovata specimens, if it proves to be a biological rather than a taphonomic structure, seems to contradict the sponge interpretation. However, given that Cambrowania ovata may represent an early ontogenetic stage of sponges (which tend to have a high proportion of organic matter in the skeleton), it is possible that the skeleton of Cambrowania ovata was flexible and the V-shaped cleft might be a taphonomic artifact due to sedimentary compaction.

In summary, Cambrowania ovata is reconstructed as a spherical organism and is interpreted as a possible bivalved arthropod, but more likely it represents an early life history stage of a sponge with a mainly organic skeleton.

\section{Conclusions}

The early Cambrian Hetang Formation contains abundant articulated sponge fossils, but it also yields other problematic fossils. This paper describes one of these problematic fossils, Cambrowania ovata Tang and Xiao, n. gen. n. sp., mostly preserved as carbonaceous compressions in the middle Hetang Formation. As preserved, Cambrowania ovata is characterized by a subcircular structure with a network of crossbars that may have been internally hollow. Some specimens have an aperture-like structure, whereas a few have a V-shaped cleft. It is reconstructed as a spheroidal organism. Although we cannot rule out the possibility that Cambrowania ovata may represent the carapaces of a bivalved arthropod, it is more likely a spheroidal juvenile sponge with a mostly organic skeleton. Despite the phylogenetic uncertainty, Cambrowania ovata adds to the taxonomic diversity of the Hetang biota in early Cambrian deepwater environments.

\section{Acknowledgments}

This research was supported by National Science Foundation (EAR 1528553), NASA Exobiology and Evolutionary Biology (80NSSC18K1086), National Natural Science Foundation of China (41502010), Geological Society of American, Natural Sciences and Engineering Research Council of Canada, Paleontological Society, and Society for Sedimentary Geology. We thank J.P. Botting and D.E.G. Briggs for discussion, J. Wang for field assistance, and B. Bomfleur and an anonymous reviewer for constructive criticism on an early version of the manuscript. SPL thanks N. Boury-Esnault and J. Vacelet and the staff at the Station Marine d'Endoume, Marseille, France.

\section{References}

Botting, J.P., and Muir, L.A., 2018, Early sponge evolution: A review and phylogenetic framework: Palaeoworld, v. 27, p. 1-29.

Botting, J.P., Muir, L.A., Xiao, S., Li, X., and Lin, J.-P., 2012, Evidence for spicule homology in calcareous and siliceous sponges: Biminerallic spicules in Lenica sp. from the early Cambrian of South China: Lethaia, v. 45, p. $463-475$.

Botting, J.P., Yuan, X., and Lin, J.P., 2014, Tetraradial symmetry in early poriferans: Chinese Science Bulletin, v. 59, p. 639-644.

Braun, A., Chen, J., Waloszek, D., and Maas, A., 2007, First early Cambrian Radiolaria, in Vickers-Rich, P., and Komarower, P., eds., The Rise and Fall of the Ediacaran Biota: London, Geological Society of London, Special Publications, p. 143-149.

Briggs, D.E.G., Liu, H.P., McKay, R.M., and Witzke, B.J., 2015, Bivalved arthropods from the Middle Ordovician Winneshiek Lagerstätte, Iowa, USA: Journal of Paleontology, v. 89, p. 991-1006.

Bureau of Geology and Mineral Resources of Anhui Province, 1987, Regional Geology of Anhui Province. Chinese Ministry of Geology and Mineral Resources, Geological Memoirs, series 1, number 5: Beijing, Geological Publishing House, $721 \mathrm{p}$.

Cai, Y., Xiao, S., Li, G., and Hua, H., 2019, Diverse biomineralizing animals in the terminal Ediacaran Period foreshadow the Cambrian Explosion: Geology, doi .org /10 .1130/G45949.1.

Chen, Z., Hu, J., Zhou, C., Xiao, S., and Yuan, X., 2004, Sponge fossil assemblage from the early Cambrian Hetang Formation in southern Anhui: Chinese Science Bulletin, v. 49, p. 1625-1628. [in Chinese with English summary]

de Cook, S.C., and Bergquist, P.R., 2002, Family Irciniidae Gray, 1867, in Hooper, J.N.A., Van Soest, R.W.M., and Willenz, P., eds., Systema Porifera: A Guide to the Classification of Sponges: Boston, Springer, p. 1022-1027.

Dong, L., Song, W., Xiao, S., Yuan, X., Chen, Z., and Zhou, C., 2012, Microand macrofossils from the Piyuancun Formation and their implications for the Ediacaran-Cambrian boundary in southern Anhui: Journal of Stratigraphy, v. 36, p. 600-610. [in Chinese with English summary]

Dong, X., Cunningham, J.A., Bengtson, S., Thomas, C.-W., Liu, J., Stampanoni, M., and Donoghue, P.C.J., 2013, Embryos, polyps and medusae of the early Cambrian scyphozoan Olivooides: Proceedings of the Royal Society B: Biological Sciences, v. 280, 20130071.

Dong, X., Knoll, A.H., and Lipps, J.H., 1997, Late Cambrian Radiolaria from Hunan, China: Journal of Paleontology, v. 71, p. 753-758.

Ehrlich, H., et al., 2013, Discovery of 505-million-year old chitin in the basa demosponge Vauxia gracilenta: Scientific Reports, v. 3, p. 3497.

Erwin, D.H., and Valentine, J.W., 2013, The Cambrian Explosion: The Construction of Animal Biodiversity: Greenwood Village, Colorado, Roberts and Company, $406 \mathrm{p}$.

Erwin, D.H., Laflamme, M., Tweedt, S.M., Sperling, E.A., Pisani, D., and Peterson, K.J., 2011, The Cambrian conundrum: Early divergence and later ecological success in the early history of animals: Science, v. 334, p. 1091-1097.

Fu, D., and Zhang, X., 2011, A new arthropod Jugatacaris agilis n. gen. n. sp. from the early Cambrian Chengjiang biota, South China: Journal of Paleontology, v. 85 , p. 567-586. 
Fu, D., Zhang, X., and Shu, D., 2009, Soft anatomy of the early Cambrian arthropod Isoxys curvirostratus from the Chenjiang biota of South China with a discussion on the origination of great appendages: Acta Palaeontologica Polonica, v. 56, p. 843-852.

He, S., and Yu, G., 1992, The small shelly fossils from the Palaeocambrian Meishucunian Stage in western Zhejiang: Zhejiang Geology, v. 8, p. 1-7. [in Chinese with English summary]

Hill, M.S., et al., 2013, Reconstruction of family-level phylogenetic relationships within Demospongiae (Porifera) using nuclear encoded housekeeping genes: PLoS ONE, v. 8, e50437.

Holmes, J.D., García-Bellido, D.C., and Lee, M.S.Y., 2018, Comparisons between Cambrian Lagerstätten assemblages using multivariate, parsimony and Bayesian methods: Gondwana Research, v. 55, p. 30-41.

Hou, X., and Bergström, J., 1997, Arthropods of the Lower Cambrian Chengjiang fauna, southwest China: Fossils and Strata, v. 45, p. 1-116.

Hu, J., Chen, Z., Yao-songWang, X., Jin-quanWang, J.Y., and Xun-lai, 2002, Sponge spicules in early Cambrian Hetang Formation, Xiuning, southern Anhui: Acta Micropalaeontologica Sinica, v. 19, p. 53-62. [in Chinese with English summary]

Knoll, A.H., and Carroll, S.B., 1999, Early animal evolution: Emerging views from comparative biology and geology: Science, v. 284, p. 2129-2137.

Leys, S.P., Kamarul Zaman, A., and Boury-Esnault, N., 2016, Threedimensional fate mapping of larval tissues through metamorphosis in the glass sponge Oopsacas minuta: Invertebrate Biology, v. 135, p. 259272.

Li, C., He, J., and Ye, H., 1990, Discovery of early Cambrian trilobites in Guichi of Anhui Province: Journal of Stratigraphy, v. 14, p. 159-160. [in Chinese with English summary]

Missarzhevsky, V.V., 1973, Konodontoobraznye organizmy iz pogranichnykh sloev kembriya i dokembriya Sibirskoj platformy i Kazakhstana [Conodontshaped organisms from Precambrian-Cambrian boundary strata of the Siberian Platform and Kazakhstan]: Trudy Instituta Geologii i Geofiziki SO AN SSSR, v. 49, p. 53-57. [in Russian]

Müller, E.B., 1894, Fauna und Flora des Golfes von Neapel und den angrenzenden Meers-Abschnitte: Herausgegeben von der Zoologischen Station zu Neapel, v. 21, p. 1-104.

Muscente, A.D., and Xiao, S., 2015, Resolving three-dimensional and subsurficial features of carbonaceous compressions and shelly fossils using backscattered electron scanning electron microscopy (BSE-SEM): PALAIOS, v. 30 , p. $462-481$.

Peng, S., Babcock, L.E., and Cooper, R.A., 2012, The Cambrian Period, in Gradstein, F.M., Ogg, J.G., Schmitz, M., and Ogg, G., eds., Geological Time Scale 2012: Oxford, Elsevier, p. 437-488.

Qian, Y., and Yin, G., 1984, Small shelly fossils from the lowest Cambrian in Guizhou: Professional Papers of Stratigraphy and Palaeontology, v. 13, p. 91-124 [in Chinese]

Steiner, M., Li, G., Qian, Y., Zhu, M., and Erdtmann, B.-D., 2003, Lower Cambrian small shelly faunas from Zhejiang (China) and their biostratigraphic implications: Progress in Natural Science, v. 13, p. 852-860.

Steiner, M., Li, G., Qian, Y., Zhu, M., and Erdtmann, B.-D., 2007, Neoproterozoic to early Cambrian small shelly fossil assemblages and a revised biostratigraphic correlation of the Yangtze Platform (China): Palaeogeography, Palaeoclimatology, Palaeoecology, v. 254, p. 67-99.

Tang, Q., Pang, K., Yuan, X., and Xiao, S., 2017, Electron microscopy reveals evidence for simple multicellularity in the Proterozoic fossil Chuaria: Geology, v. 45 , p. $75-78$.
Topsent, E., 1927, Diagnoses d'Éponges Nouvelles recueillies par le Prince Albert ler de Monaco: Bulletin de l'Institut océanographique Monaco, no. 502, p. 1-19.

Vannier, J., Caron, J.-B., Yuan, J., Briggs, D.E.G., Collins, D., Zhao, Y., and Zhu, M., 2007, Tuzoia: Morphology and lifestyle of a large bivalved arthropod of the Cambrian seas: Journal of Paleontology, v. 81, p. 445-471.

Voronova, L.G., and Missarzhevsky, V.V., 1969, Nakhodki vodoroslej i trubok chervej v pogranichnykh sloyakh kembriya i dokembriya na severe Sibirskoj platformy [Finds of algae and worm tubes in the Precambrian-Cambrian boundary beds of the northern part of the Siberian Platform]: Doklady AN SSSR, v. 184, p. 207-210. [in Russian]

Walcott, C.D., 1899, Precambrian fossiliferous formation: Geological Society of America Bulletin 19, p. 199-244.

Wu, W., Yang, A.-H., Janussen, D., Steiner, M., and Zhu, M.-Y., 2005, Hexactinellid sponges from the early Cambrian black shale of south Anhui, China: Journal of Paleontology, v. 79, p. 1403-1051.

Xiang, L., Schoepfer, S.D., Shen, S., Cao, C., and Zhang, H., 2017, Evolution of oceanic molybdenum and uranium reservoir size around the EdiacaranCambrian transition: Evidence from western Zhejiang, South China: Earth and Planetary Science Letters, v. 464, p. 84-94.

Xiao, S., Hu, J., Yuan, X., Parsley, R.L., and Cao, R., 2005, Articulated sponges from the lower Cambrian Hetang Formation in southern Anhui, South China: Their age and implications for the early evolution of sponges: Palaeogeography, Palaeoclimatology, Palaeoecology, v. 220, p. 89-117.

Xue, Y., and Yu, C., 1979, Lithological characteristics and sedimentary environments of the lower Cambrian Hetang Formation in western Zhejiang and northern Jiangxi: Journal of Stratigraphy, v. 3, p. 283-293. [in Chinese with English summary]

Yao, J., Xiao, S., Yin, L., Li, G., and Yuan, X., 2005, Basal Cambrian microfossils from the Yurtus and Xishanblaq formations (Tarim, north-west China): Systematic revision and biostratigraphic correlation of Micrhystridium-like acritarchs from China: Palaeontology, v. 48, p. 687-708.

Yuan, X., Xiao, S., Parsley, R.L., Zhou, C., Chen, Z., and Hu, J., 2002, Towering sponges in an early Cambrian Lagerstätte: Disparity between nonbilaterian and bilaterian epifaunal tierers at the Neoproterozoic-Cambrian transition: Geology, v. 30, p. 363-366.

Yuan, Y., Cai, C., Wang, T., Xiang, L., Jia, L., and Chen, Y., 2014, Redox condition during Ediacaran-Cambrian transition in the Lower Yangtze deep water basin, South China: Constraints from iron speciation and $\delta^{13} \mathrm{C}_{\text {org }}$ in the Diben section, Zhejiang: Chinese Science Bulletin, v. 59, p. $3638-3649$.

Yue, Z., and He, S., 1989, Early Cambrian conodonts and bradoriids from Zhejiang: Acta Micropalaeontologica Sinica, v. 6, p. 289-300. [in Chinese with English summary]

Yue, Z., and Zhao, J., 1993, Meishucunian (early Cambrian) rod-like fossils from western Zhejiang: Acta Micropalaeontologica Sinica, v. 10, p. 8997. [in Chinese with English summary]

Zhou, C., and Jiang, S., 2009, Palaeoceanographic redox environments for the lower Cambrian Hetang Formation in South China: Evidence from pyrite framboids, redox sensitive trace elements, and sponge biota occurrence: Palaeogeography, Palaeoclimatology, Palaeoecology, v. 271, p. 279-286.

Zhu, M., Zhuravlev, A.Y., Wood, R.A., Zhao, F., and Sukhov, S.S., 2017, A deep root for the Cambrian Explosion: Implications of new bio- and chemostratigraphy from the Siberian Platform: Geology, v. 45, p. 459-462.

Accepted: 1 April 2019 